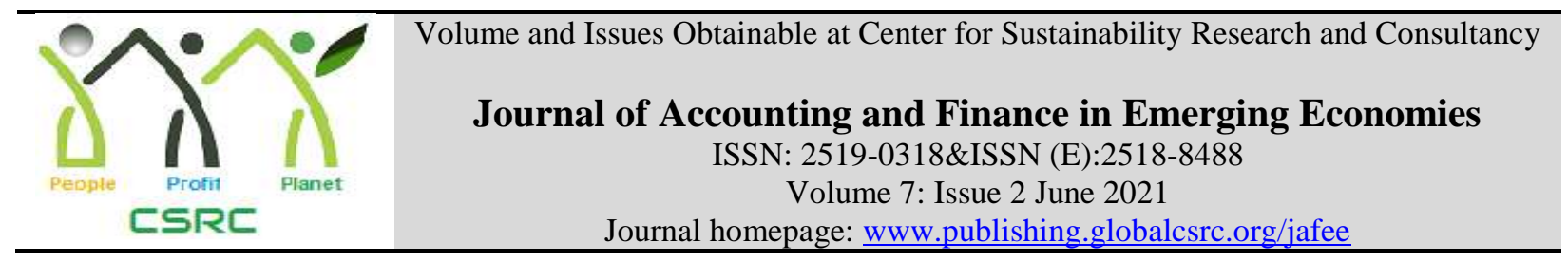

\title{
Impact of Tourism Receipts, FDI and Energy Usage on Economic Growth in South Asia
}

Farhana Nosheen, Department of Economics, Government Associate college for women, Muzafrabad, Multan, Pakistan

*Umar Suffian Ahmad, Visiting Lecturer, Department of Economics, Ghazi University, DGKhan, Pakistan

Sadia Anjum, Department of Economics, Bahauddin Zakariya University, Bahadur Campus

Layyah, Pakistan

Robina Kouser, Department of Economics, University of Sahiwal, Sahiwal, Pakistan

*Corresponding author's email address: umarsuffianahmad @ gmail.com

\begin{tabular}{l}
\hline ARTICLE DETAILS \\
\hline History \\
Revised format: May 2021 \\
Available Online: Jun 2021
\end{tabular}

Keywords

Tourism, FDI, Energy, Economic Growth, South Asia

JEL Classification

$\mathrm{O} 1, \mathrm{O} 20$

\begin{abstract}
Purpose: The study examines the significant and direct influence of FDI and tourism income on economic growth in selected South Asian countries.

Design/Methodology/Approach: The study has made use of ARDL regression methodology to analyze the influence of tourism receipts, FDI and energy usage on economic growth. Findings: This study shows a strong long-term FDI, tourist receipts, and energy links, whereas the effects of these variables are less valuable in the short term. Implications/Originality/Value: It is generally recognized that FDI accompanies general economic expansion, the development of tourism, and the use of energy around the globe. However, several empirical outcomes have been disclosed in a long-standing discussion.
\end{abstract}

(C) 2021 The authors, under a Creative Commons AttributionNonCommercial 4.0

Recommended citation: Nosheen, F., Ahmad, U. S., Anjum, S. and Kouser, R. (2021). Impact of Tourism Receipts, FDI and Energy Usage on Economic Growth in South Asia. Journal of Accounting and Finance in Emerging Economies, 7 (2), 337-347

\section{Introduction}

International tourism attracts inbound tourists and has a pivotal role in earning foreign income. Generally, the contribution of international tourism is assessed by the impact of international tourism on economic growth. The primary drive of international tourism is the country's exchange rate and extensive (inbound tourists) margins and many other factors like infrastructure development, improvement in transportation, and accommodation services that help boost the economic benefits of international tourism (Tohidy Ardahaey, 2011). Foreign direct investment (FDI) inflows are another factor that moves the economic growth rate. FDI impacts economic growth based on the economy's physical assets, technology, capital formation, and innovative capacity (Abbas et al., 2020b). FDI accelerates economic growth directly and indirectly (Doytch and Uctum, 2011) (Hanif et al., 2019). The indirect effect of FDI can be analyzed through 
smoothing the capital finance and producing positive externalities in diverse sectors of the destination country, especially the tourism sector. Improvement of managerial skills in the tourism industry has long-lasting and diverse benefits like stimulating economic growth and tax collection from the tourism industry. Meanwhile, there exists a complex nexus among economic growth, foreign direct investment inflows, and tourism receipts. This complex relationship also has prime importance for making consistent economic policies.

Travel and Tourism Competitiveness Index is a report of the World Economic Forum published biannually, indicating the benchmark of T\&T competitiveness of 140 economies. This index has four subindexes with 14 pillars with several individual indicators.

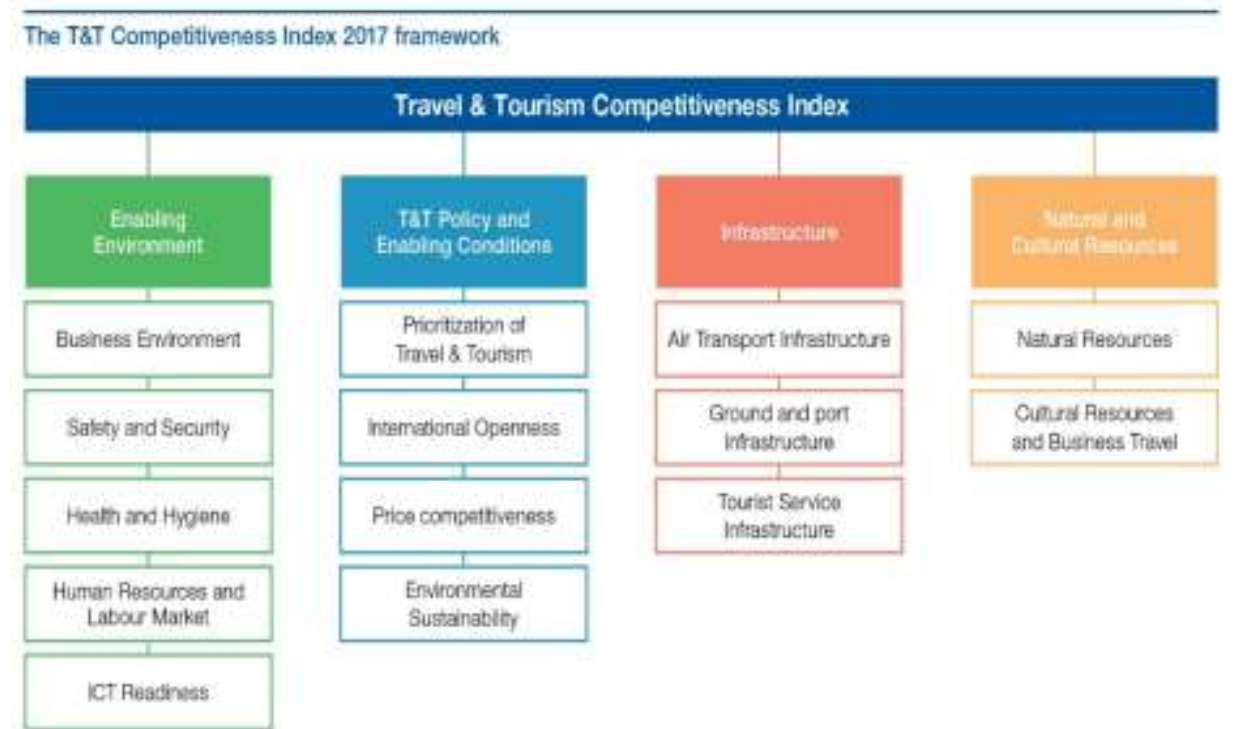

Figure 1:T\&T competitiveness 2017

Moreover, the number of indicators is distributed among different pillars. The area of this research includes 30 out of 90 indicators from 14 pillars. These 30 indicators are distributed among four perspectives like [(i) Economic impact of tourism development, (ii) Socio-cultural impact of tourism development, (iii) Environmental impact of tourism development, and (iv) Community impact of tourism development]. Developing economies of south Asia are also the leading players in this process. For example, Pakistan stands at 121 numbers with 3.1 scores. Moreover, it has a negative (-19.5\%) average change from the global change. Although the change since 2017 is $7.1 \%$ which is a positive sign showing that the tourism industry is improving over the last two years.

This research study includes 5 South Asian countries Bangladesh, India, Nepal, Pakistan, Sri Lanka. Travel and tourism have an $8.8 \%$ contribution to the total GDP with worth USD295.6BN in South Asia. It shows positive 7.2\% Travel and Tourism GDP growth in 2018 (Travel and Tourism Competitive Index 2018). In South Asia, 51.1 MN jobs were created by Travel and Tourism, which comprises about $7.6 \%$ of total employment. There is a forecast of about $63.6 \mathrm{MN}$ jobs created in 2029 through travel and tourism in South Asia. In South Asia, total spending by inbound visitors is 39.4BN covering 6.2\% of total exports. In South Asia, sector characteristics of travel tourism include $94 \%$ spending on leisure travel and tourism, and $6 \%$ is business travel and tourism.

Therefore, this study intends to produce more accurate statistics on the links between economic growth, FDI, and tourism receipts using the ARDL framework. ARDL is a valuable cointegration technique for finding the short-run and long-run relationships of considered variables. Most empirical studies have used other techniques like cointegration and causality test, which validate 
the directly proportional impacts of tourism receipts or FDI on economic growth and vice versa (World Travel \& Tourism Council, 2018);(Hazari and A-Ng, 1993; Hazari and Sgro, 1995) (Li et al., 2020). There have been several research, but there is still a dearth of empirical evidence about economic growth, FDIs, and the linkage between tourism receipts. More typically, improper methodologies and factors lead to unclear outcomes.

The remaining paper is managed section-wise: Section 2 is the brief literature review. Section 3 gives a theoretical framework and model specifications; following Section 4, empirical results are discussed, and the final section 5 offers the study's conclusion. Section 6 proposes recommendations for future studies.

\section{Literature Review}

(Sahban and Abbas, 2018) examined tourism as a significant factor of economic activity. Tourism accounts for $2.1 \%$ inflow of the total number of tourists in the European Union and 18\% of GDP. (Qayyum et al., 2019) revealed tourism geography and economic geography and found a lack of diverse studies in economics-based tourism research. (Anser et al., 2020b) presented a substantial positive economic impact on any country. Tourism attracts international visitors with foreign exchange inflow. It creates jobs, stimulates enterprise to open a new business and increase in government revenue. (Iram et al., 2020) conducted preliminary qualitative studies for measuring the emerging economy with tourism aspects. (W. Iqbal et al., 2020) used Granger noncausality method is used vector auto-regression (VAR) is used to attempt to improve forecasting tourism studies. (Anser et al., 2020a) found short-run bidirectional Granger causality between health care development and tourism. (Abbas et al., 2020a) examined the relation of the tourism industry with crisis and disaster management. (N. Iqbal et al., 2020) summarized both positive and negative consequences of tourism through residents' perception. Results revealed that tourism has a positive impact and is essential for economic development. (Sun et al., 2020) examined the socio-demographic structure of the population that was affected because of migration from other areas in a Spanish coastal resort. (Abbas et al., 2020b) examined a significant effect on the perception of tourism impact due to different socio-demographic factors. (Li et al., 2020) described tourism as a multi-faced activity that links sustainability's socioeconomic and environmental components. Beekhuis (1981) provided the tourism impact on direct employment in the hospitality sector, including accommodation, eating, and beverages sector. (Ali et al., 2021) researched that tourism increases tourist arrivals from different countries and regions.

(Yang et al., 2021) found no causal relationship between tourism and economic growth. The study focus was Brazil, Russia, China, and the USA. Panel causality test was used for estimation of tourism-led growth. No relationship was found between economic performance and tourism expenditure for 98 countries, using two-stage least square estimation (Huang et al., 2020). VAR model and Impulse Response function confirmed the tourism-led growth hypothesis in three emerging market countries like the Philippines, Mexico, and Brazil. However, an opposite relationship was found in Peru, Malaysia, Indonesia, India, and China (Amin et al., 2021). (Hanif et al., 2019) found no significant relationship in determining factors in a close relationship between tourism receipts and economic growth in African, Asian, and European countries at the Mediterranean Sea border. (Xia et al., 2020) explored a significant effect of tourism receipt on the gross domestic product. The panel cointegration test was applied to find the relation between two variables, tourism receipts, and GDP. A research study by (Shen et al., 2021) has been conducted in seven Mediterranean countries.

(Li and Liu, 2005) argued the FDI, economic growth nexus based on a set of panel data for 84 economies. The time series period is between 1970-1999 to find the relationship between two techniques i.single equation and ii. Simultaneous equation system techniques were used. From 
the mid-1980s onward, a significant endogenous relationship was found among the variables. The study reveals that there is not only a direct effect of FDI on economic growth but an indirect effect of FDI on economic growth through interaction terms. Based on the best of our knowledge, investigating the short-run and long-run nexus of FDI, tourism receipts, and economic growth is the first attempt for South Asian countries using the ARDL model.

\section{Research Methodology}

The panel data is obtained from World Development Index (WDI) based on annual time series. The data comprises panel data with six cross-section countries of South Asia throughout 19952018. Study variables are: International Tourism Recipes at the current US\$, GDP Growth (yearly percentage), FDI inflows( percent of GDP). The share of GDP derived from international receipts for tourism comes through the form of dividing international revenue for tourism by GDP to the current US\$. Table 1 depicted variables and their unit of measurement used for estimation of panel data.

A ceteris paribus analysis presupposes estimating the expected value of GDP conditional on tourism receipt (TR), and $\mathrm{c}$, where $\mathrm{c}=($ EUS $)$. The vector $\mathrm{c}-$ whose dimension is least valuable for discussion, denotes a set of control variables (Liu et al., 2021). These control variables are held constant when studying the effect of tourism receipts on economic growth. However, the log of gross domestic product (LGDP) is taken as the proxy of economic growth. Following is the functional form of the model.

$G D P=f(T R, F D I, E U S, P C I)$

\section{Econometric Model is given below}

$G D P=\beta_{0}+\beta_{1} T R+\beta_{2} F D I+\beta_{3} E U S+\beta_{4} P C I+u_{i}$

Where GDP = economic growth

TR $=$ Tourism Receipt

EUS = Energy usage

$\mathrm{FDI}=$ Foreign direct investment

PCI $=$ Per capita income

The functional form of the model specification is exhibited in equation (1) below:

$\operatorname{Ln}\left(\mathrm{GDP}_{\mathrm{t}}\right)=\beta_{0}+\beta_{1} \operatorname{Ln}\left(\mathrm{TR}_{\mathrm{t}}\right)+\beta_{2} \operatorname{Ln}\left(\mathrm{EUS}_{\mathrm{t}}\right)+\beta_{3} \mathrm{Ln}\left(\mathrm{FDI}_{\mathrm{t}}\right)+\beta_{4} \operatorname{Ln}\left(\mathrm{PCI}_{\mathrm{t}}\right)+\varepsilon_{t}$

While the ARDL model stands for the autoregressive distributed lagged model, the advantages of the ARDL model are that it describes both short and long period relation in the model. Here lag of both dependent and independent variables are used in the model. Mathematically, described as. $\operatorname{LnGDP} P_{i, t}=\alpha+\sum_{i, t=1}^{p} \beta_{1}(G D P)_{t-1}+\sum_{i, t=0}^{q} \gamma_{i, t} Z_{i, t-1}+\mu_{i, t}$

In eq(4) $\mathrm{i}=1,2 \ldots \mathrm{N}$ and $\mathrm{t}=1,2 \ldots \mathrm{T}$ and the vector $\mathrm{Z}_{\mathrm{it}}$ shows all the independent variables included in the model. Log Model equation (5) depicts the short-run and model equation (6) the long-run ARDL assessed condition, while the standard condition is tested on the cross-section in the econometric model (2). It creates an error correction symbol if there is a long-run relationship. From that point, the error correction model is additionally assessed with the shortrun estimates. The ECM error correction model commonly speaks to the velocity of alteration back to its long period because of advancement or stun. Thus, the error correction assessments are the long-term phenomena of the ARDL, acquired to given the condition as a portrayal of the error correction.

$$
\begin{aligned}
\Delta \operatorname{Ln}\left(\mathrm{GDP}_{\mathrm{t}-1}\right) & =S_{0}+\sum_{i=1}^{n I} \beta_{1} \Delta \operatorname{Ln}\left(\mathrm{GDP}_{\mathrm{t}-1}\right)+\sum_{i=0}^{n I I} \beta_{2} \Delta \operatorname{Ln}\left(\mathrm{TR}_{\mathrm{t}-1}\right)+\sum_{i=0}^{n I I I} \beta_{3} \Delta \operatorname{Ln}\left(\mathrm{EDUs}_{\mathrm{t}-1}\right) \\
& +\sum_{i=0}^{n I V} \beta_{4} \Delta \operatorname{Ln}\left(\mathrm{FDI}_{\mathrm{t}-1}\right)+\sum_{i=0}^{n V} \beta_{5} \Delta \operatorname{Ln}\left(\mathrm{PCI}_{\mathrm{t}-1}\right)+\mathrm{Tecm}_{\mathrm{t}-\mathrm{i}}+\varepsilon_{t}
\end{aligned}
$$




$$
\begin{aligned}
& \operatorname{Ln}\left(\mathrm{GDP}_{\mathrm{t}-1}\right)=\alpha_{0}+ \beta_{1} \operatorname{Ln}\left(\mathrm{GDP}_{\mathrm{t}-1}\right)+\beta_{2} \operatorname{Ln}\left(\mathrm{TR}_{\mathrm{t}-1}\right)+\beta_{3} \operatorname{Ln}\left(\mathrm{EUs}_{\mathrm{t}-1}\right)+\beta_{4} \operatorname{Ln}\left(\mathrm{FDI}_{\mathrm{t}-1}\right)+\beta_{5} \operatorname{Ln}\left(\mathrm{PCI}_{\mathrm{t}-1}\right) \\
&+\sum_{i=1}^{n I} L_{1} \Delta \operatorname{Ln}\left(\mathrm{GDP}_{\mathrm{t}-1}\right)+\sum_{i=0}^{n I I} L_{2} \Delta \operatorname{Ln}\left(\mathrm{TR}_{\mathrm{t}-1}\right)+\sum_{i=0}^{n I I} L_{3} \Delta \operatorname{Ln}\left(\mathrm{EUs}_{\mathrm{t}-1}\right) \\
&+\sum_{i=0}^{n V} L_{4} \Delta \operatorname{Ln}\left(\mathrm{FDI}_{\mathrm{t}-1}\right)+\sum_{i=0}^{n V} L_{5} \Delta \operatorname{Ln}\left(\mathrm{PCI}_{\mathrm{t}-1}\right)+\varepsilon_{t}
\end{aligned}
$$

Fisher-PP and Fisher-ADF type, Im, Pesaran, Shin (2003) Levin, Lin, and Chu (2002) are existing in table no 5. The Levin et al. (2002) panel unit root test describes the ADF specified in the equation.

$$
\Delta x_{i, t}=\delta_{i} x_{i, t-1}+\sum_{i=1}^{\delta} \theta_{i, t} \Delta x_{i, t-1}+\mu_{i, t}
$$

The parameter of $\delta_{i}$ is equivalent in cross-sections that is $\delta_{i}=\delta$ for all $i$ and the lagged order might not same across cross-sections. This procedure assesses the Null hypothesis $\delta_{i}=0$ for all $\mathrm{i}$ against its other $\delta_{i}<0$ for all $\mathrm{i}$. So the decision leads us to use the panel cointegration methods.

In order to use the co-integration test, we must check the stationarity of the variable because it is essential for the test to become stationary. So all of our variables are stationary at the first difference; we use the Autoregressive distributed lagged model, which shows both long-run and short-run relationships in the model. The short-run and the long-run results are listed in table no 6. The short-run model for the ECM error correction model is given below.

$$
\begin{aligned}
\Delta \operatorname{Ln}\left(\mathrm{GDP}_{\mathrm{t}-1}\right) & =S_{0}+\sum_{i=1}^{n I} \beta_{1} \Delta \operatorname{Ln}\left(\mathrm{GDP}_{\mathrm{t}-1}\right)+\sum_{i=0}^{n I I} \beta_{2} \Delta \operatorname{Ln}\left(\mathrm{TR}_{\mathrm{t}-1}\right)+\sum_{i=0}^{n I I I} \beta_{3} \Delta \operatorname{Ln}\left(\mathrm{EDUs}_{\mathrm{t}-1}\right) \\
& +\sum_{i=0}^{n I V} \beta_{4} \Delta \operatorname{Ln}\left(\mathrm{FDI}_{\mathrm{t}-1}\right)+\sum_{i=0}^{n V} \beta_{5} \Delta \operatorname{Ln}\left(\mathrm{PCI}_{\mathrm{t}-1}\right)+\mathrm{Tecm}_{\mathrm{t}-\mathrm{i}}+\varepsilon_{t}
\end{aligned}
$$

Table 1: Unit of Measurement and Variable Description of Variables

\begin{tabular}{lcll}
\hline VARIABLES & SIGN & VARIABLE DESCRIPTION & UNIT OF MEASUREMENT \\
\hline Gross Domestic Product & LGDP & Gross domestic product (GDP) current US\$ & Log of GDP (current US\$)
\end{tabular}

$\begin{array}{lll}\begin{array}{l}\text { International Tourism } \\ \text { Receipts }\end{array} & \begin{array}{l}\text { International tourism receipts include all the Log of International tourism, } \\ \text { LTR }\end{array} \\ \text { expenditures by international inbound visitors. } & \begin{array}{l}\text { receipts (current US\$) }\end{array}\end{array}$

Foreign Direct Investment LFDI FDI is the net inflows. (FDI)

Energy Usage $\quad$ EUS
Log of Foreign direct investment, net inflows (current US\$)

Energy use (kg of oil equivalent per capita)

Table 1 shows the description of variables and their sign. All variables are taken in log form. GDP is explained variable and is taken in log form. GDP was taken in term is current US\$. At the same time, other explanatory variables are tourism receipts TR, foreign direct investment FDI and per capita income PCI. The unit of measurement was current US\$ taken in log form. However, the unit of measurement of one of the explanatory variable energy usage EUS is $\mathrm{kg}$ of oil equivalent per capita. Energy usage has a strong relation with economic growth(Akadiri et al., 2019; Beyzatlar et al., 2014).

Table 2: Chronological order of Countries with Highest International Tourism Receipt (\% of GDP) in 2018

\begin{tabular}{llll}
\hline Sr No. & Country & \% of GDP & Billion USD \\
\hline 1 & Sri Lanka & $6.27 \%$ & 5.58 \\
2 & Nepal & $3.21 \%$ & 0.93 \\
\hline
\end{tabular}




\begin{tabular}{llll}
\hline 3 & India & $1.20 \%$ & 32.65 \\
4 & Pakistan & $0.31 \%$ & 0.96 \\
5 & Bangladesh & $0.17 \%$ & 0.47 \\
\hline
\end{tabular}

Sources: World Development Indicators

Table 2 depicts the chronological ranking of tourism receipts as a percentage of GDP of five South Asian countries for the year 2018. Sri Lanka ranks first in tourism receipts percentage with 5.58billion US\$. The percentage share of tourism receipts is $6.27 \%$. Nepal has the second number in terms of percentage share with $3.21 \%$. The net worth of tourism receipts is 0.93 billion US\$. India and Pakistan have a third and fourth number in percentage share of tourism receipts with $1.20 \%$ and $0.31 \%$. Bangladesh ranks last in five South Asian countries with $0.17 \%$ tourism receipts as a percentage of GDP. One other aspect is that India is the only country with the highest tourism receipts of 32.65 billion US\$.

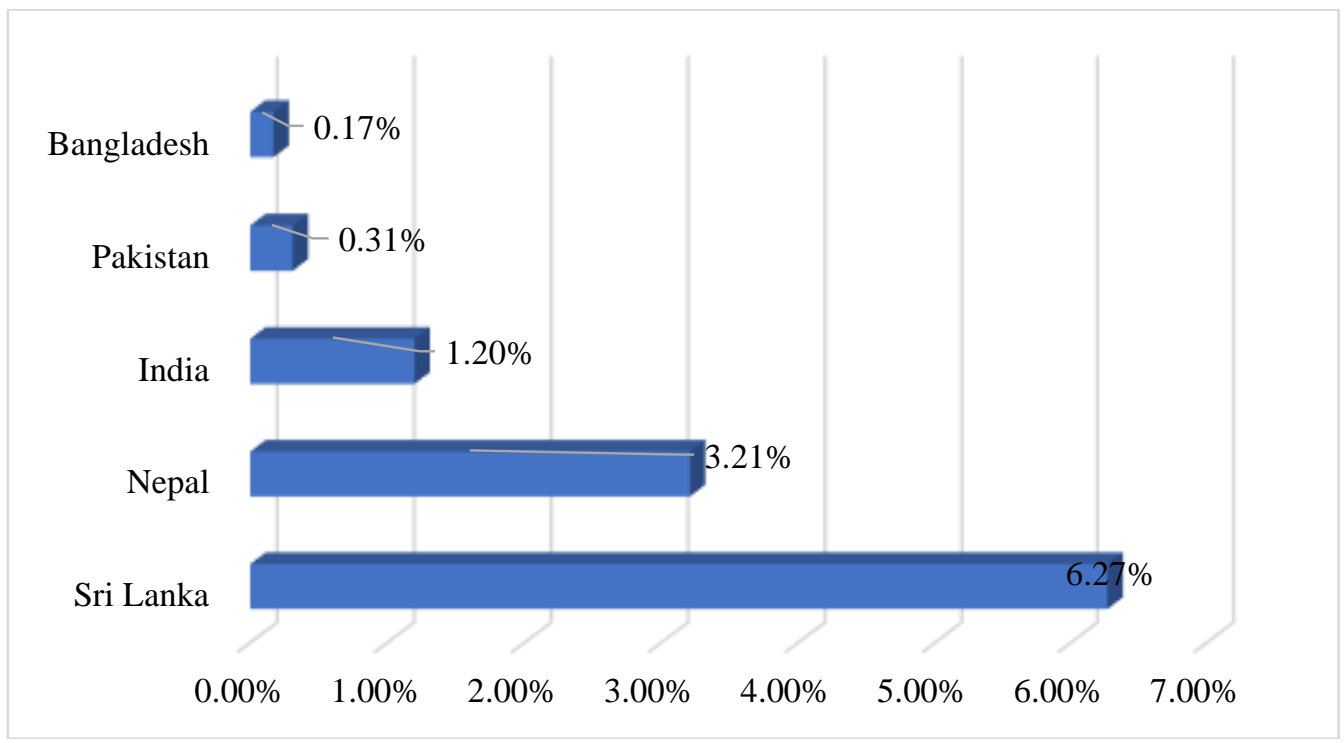

Figure 2: Tourism Receipts as a Percentage of GDP

Figure 2 is the representation of the data provided in Table 1. It shows the share of tourism receipts from GDP in percentage terms. While table 3 and figure 3 show the FDI as a percentage of GDP for the year 2018. In terms of FDI as a percentage of GDP, Sri Lanka again stands first. While India has a second number and Bangladesh is the third in the list.

Table 3: Chronological Order of Countries with Highest FDI (\% of GDP) in 2018

\begin{tabular}{llr}
\hline Sr No. & Country & $\%$ of GD \\
\hline 1 & Sri Lanka & $1.81 \%$ \\
2 & India & $1.54 \%$ \\
3 & Bangladesh & $1.07 \%$ \\
4 & Pakistan & $0.75 \%$ \\
5 & Nepal & $0.56 \%$
\end{tabular}




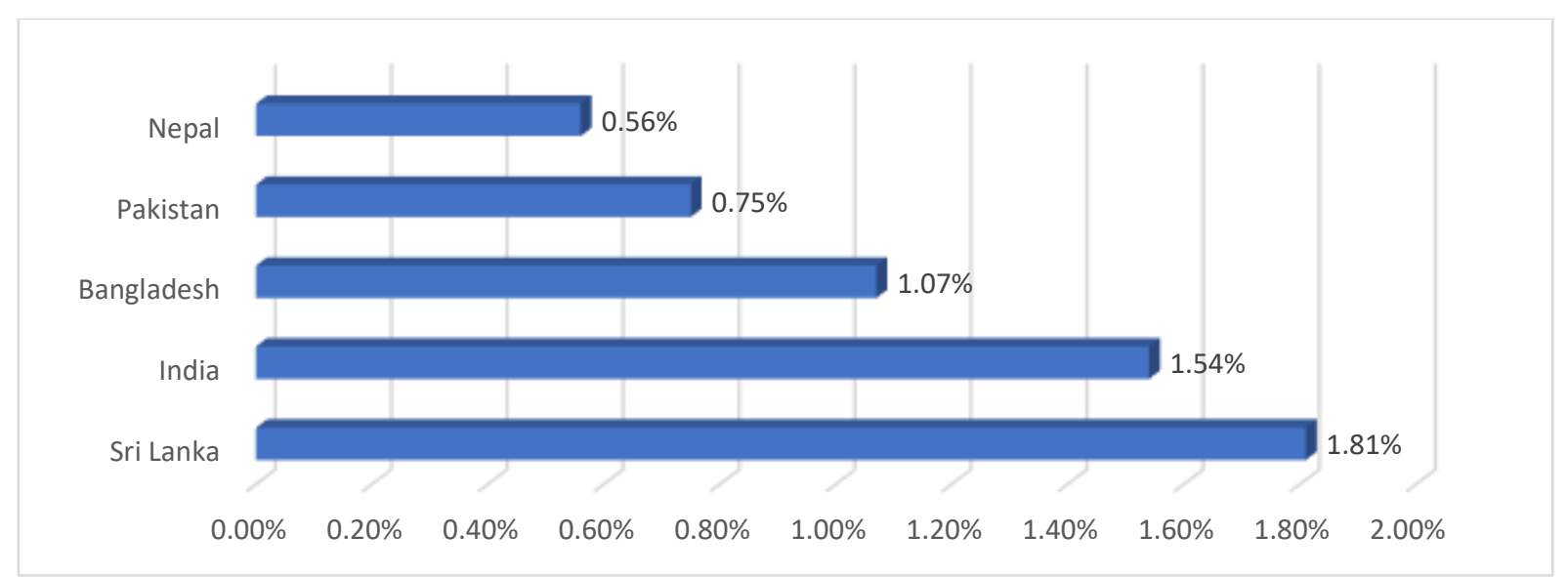

Figure 3: FDI as a percentage of GDP

\section{Normality of Data and Descriptive Summary}

Table 4 shows the descriptive summary of the variables. In Figure 4 graph is a histogram which is the visual representation of the normality of data. It contains the Jarque Bera value, which shows the asymptotical chi-square distribution of data. JB value matches the skewness and kurtosis for the normal distribution of data. Jb value can be calculated:

$$
\mathrm{JB}=\frac{n}{6} \cdot\left(S^{2}+\frac{(K-3)^{2}}{4}\right)
$$

The P-value of Jarque Bera less than 5\% indicates that data is usually distributed. So we have a $\mathrm{JB}$ value of 343.34 with a probability value of 0.0000 . So, we can reject our null hypothesis: data is not normally distributed. Therefore, we accept that data is normally distributed along with its mean. The data descriptive statistics show in Table 4 for further understanding in this regard.

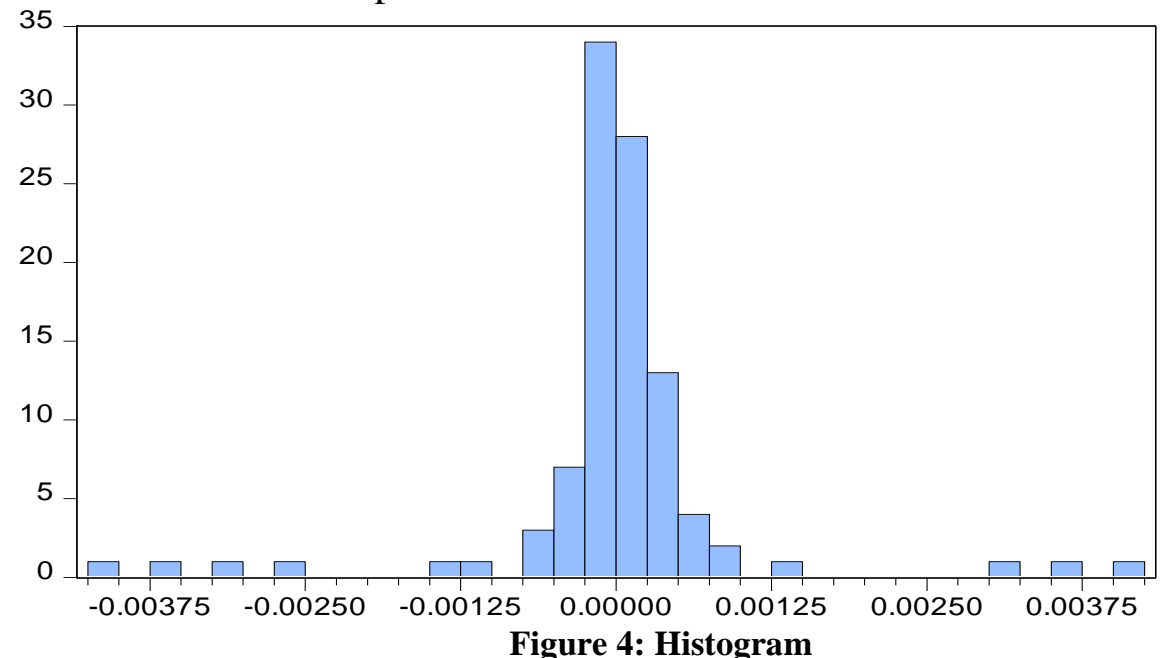

$\begin{array}{lr}\text { Series: Residuals } \\ \text { Sample 1995 } 2018 \\ \text { Observations } 101 \\ \text { Mean } & -6.52 \mathrm{e}-08 \\ \text { Median } & 5.26 \mathrm{e}-07 \\ \text { Maximum } & 0.004018 \\ \text { Minimum } & -0.004040 \\ \text { Std. Dev. } & 0.000990 \\ \text { Skewness } & -0.200017 \\ \text { Kurtosis } & 12.02362 \\ & \\ \text { Jarque-Bera } & 343.3404 \\ \text { Probability } & 0.000000\end{array}$

Figure 4: Histogram

Table 4: Descriptive Summary

\begin{tabular}{llccc}
\hline & LGDP & LFDI & EUS & LTR \\
\hline & & & & \\
Mean & 10.91933 & 8.834002 & 2.56882 & 8.822464 \\
Median & 10.85919 & 8.933993 & 2.54544 & 10.44526 \\
Maximum & 12.43558 & 10.64796 & 2.842177 & 7.397940 \\
Minimum & 9.643562 & 5.997877 & 2.133337 & 0.716842 \\
Std. Dev. & 0.717746 & 0.996014 & 0.176648 & 0.406148 \\
Skewness & 0.254610 & -0.374314 & -0.370188 & 2.626794 \\
Kurtosis & 2.395657 & 3.212869 & 2.727384 & $3.829050^{* *}$ \\
Jarque-Bera & $3.122677 * *$ & $2.902583 * *$ & $3.112379 * *$ & 0.014741 \\
Probability & 0.020985 & 0.023426 & 0.021093 & 1014.583 \\
Sum & 1310.319 & 1015.910 & 308.260 & 58.58028 \\
Sum Sq. Dev. & 61.30403 & 113.0931 & 20.5310 & \\
\hline
\end{tabular}




\begin{tabular}{|c|c|c|c|c|}
\hline$\overline{\text { Observations }}$ & 120 & 120 & 120 & 120 \\
\hline
\end{tabular}

According to (Brooks 2014) and (Gujarati 2004), before running Auto-regressive Distributed Lag ARDL model is used to check the stationarity of the series. If the stationarity of the series is not checked, it will give spurious results. Therefore, we have performed the panel unit test. According to the outcome so this unit root rest in Table 5, all the variables are stationary at level and $1 \%$ level of significant. Therefore, we reject the null hypothesis of unit root in the dataset and accept the alternative hypothesi of no unit root issue in this data set. Thus, all the variables are stationary at the first difference; then, we have used the ARDL model.

Table 5: Unit Root Summary

\begin{tabular}{|c|c|c|c|c|c|}
\hline Variables & Levin, Lin \& Chu t* & $\begin{array}{r}\text { Im, Pesaran } \\
\text { Shin W }\end{array}$ & & ADF & PP-Fisher Chi-sqaure \\
\hline LGDP & $\begin{array}{r}-3.42837 * * * \\
(0.0003)\end{array}$ & $\begin{array}{l}-2.68934 * * * \\
(0.0036)\end{array}$ & $(0.0066)$ & $\begin{array}{r}27.4957 * * * \\
(0.0000)\end{array}$ & $* * \mathrm{I}(1)$ \\
\hline LTR & $\begin{array}{c}-4.91153 * * * \\
(0.0000)\end{array}$ & $\begin{array}{l}-4.9079 * * * \\
(0.0000)\end{array}$ & $(0.0000)$ & $\begin{array}{l}46.5786 * * * \\
(0.0000)\end{array}$ & $57.3841 * * * \mathrm{I}(1)$ \\
\hline LFDI & $\begin{array}{c}-1.75134 * * \\
(0.0399)\end{array}$ & $\begin{array}{l}-1.98015^{* *} \\
(0.0238)\end{array}$ & $(0.0141)$ & $\begin{array}{r}25.1603 * * \\
(0.0189)\end{array}$ & $24.2268 * * \quad \mathrm{I}(1)$ \\
\hline LEUS & $\begin{aligned} &-2.3004 * * \\
&(0.0107)\end{aligned}$ & $\begin{array}{l}-2.8444 * * * \\
(0.0022)\end{array}$ & $(0.0051)$ & $\begin{array}{r}28.2570 * * * \\
(0.0000)\end{array}$ & $63.5886 * * * \mathrm{I}(1)$ \\
\hline
\end{tabular}

Note: $* * *$ indicates $\mathrm{P}<1 \%$, **indicates $\mathrm{P}<5 \%$, * indicates $\mathrm{P}<10 \%$.

However, we performed a correlation matrix to identify the issue-the results of this correlation matrix presented in Table 6. According to the outcomes, variables are weakly correlated to each other, which indicates that there is no issue of correlation between variables in this data set.

Table 6: Correlation Matrix

\begin{tabular}{lllll}
\hline & LGDP & LFDI & EUS & LTR \\
\hline LGDP & 1.000000 & 0.005583 & 0.395610 & 0.480506 \\
LFDI & 0.005583 & 1.000000 & 0.487972 & 0.300073 \\
EUS & 0.395610 & 0.487972 & 1.000000 & 0.079809 \\
LTR & 0.480506 & 0.300073 & 0.079809 & 1.000000 \\
\hline
\end{tabular}

This paper examines the nexus of FDI, tourism receipts, and economic growth using the autoregressive distributed lag ARDL cointegration framework. ARDL deals with short-run and long-run dynamics. In ARDL, lagged values of the dependent variable, current values, and lagged values of explanatory variables are included. This model includes the free lags in the regression function. Table 7 shows the results of ARDL.

Table 7: Autoregressive Distributed Lag ARDL Results

\begin{tabular}{llll}
\hline & FDI & EUS & TR \\
\hline Long Run & $0.0055^{* * *}$ & $0.0003^{* * * *}$ & $0.0797^{* * * *}$ \\
& $(0.0430)$ & $(0.0000)$ & $(0.0002)$ \\
Short Run & 0.0002 & -0.00001 & 0.0028 \\
& $(0.3252)$ & $(0.2487)$ & $(0.4110)$ \\
\hline
\end{tabular}

Note: $* * *$ indicates $\mathrm{P}<1 \%$, **indicates $\mathrm{P}<5 \%$, * indicates $\mathrm{P}<10 \%$, the coefficients having No star indicates Insignificance of the variable. All variables are in log form.

According to the empirical outcomes of the ARDL method, FDI is positively and statistically significant at a 5\% level. It indicates that FDI is contributing positively to the process of 
economic growth in the South Asian region. FDI coefficient shows that one unit growth in foreign direct investment can lead to 0.005 unit growth in the economic process. Furthermore, energy usage (EUS) has a positive relationship with economic growth in this region. According to the outcomes, the energy usage coefficient has a positive sign with a $1 \%$ significance level. It means that a one-unit increase in the energy consumption in this region will enhance economic growth up to 0.0003. Finally, the revenues for tourism (TR) affect this region's economic growth beneficially and importantly. A one-unit increase in tourist revenue can contribute up to 0.079 units to boost economic growth.

Although these results contrasted the FDI, EUS, and TR connections to long-term economic growth in the South Asian area, all indicators in the short run are inconsequential. All these determinants do not substantially impact South Asian economies in the short term on economic growth.

\section{Results and Interpretation}

This study utilized the impact of tourism receipts, energy consumption, and FDI on the economic process in the five selected economies of South Asia. This study finds that tourism receipts and long-term economic growth have a significant favorable association. The explanatory variable FDI shows a positive contribution to economic growth. (Samad, 2009) found a bidirectional relation between FDI and economic growth for two Latin American and five East and South Asian countries. (Belloumi, 2014) examined a significant contribution of FDI in economic growth in the long run. The study results indicate a positive relationship between energy usage and economic growth supported by the concept of the Environmental Kuznets curve (EKC) (Apergis and Payne, 2009). There is a complex pattern of relationship found among environmental scenarios and economic growth.

According to our findings of a research study on tourism nexus economic growth, the expansion of international tourism is one of the critical essential factors for economic growth in South Asian countries. Previous studies are evident about the significant role of tourism in the improvement of standards in Spain and other European countries. One other to boost economic growth is subsidizing tourism and providing privileges to the tourism and entertainment industry. The arrival of both inbound and outbound tourists to tourism destinations enhances the tourism receipts and foreign exchange earnings. In order to gain benefit from tourism, this study suggests that governments must step in developing a policy to foster conferences and festivals and improve service.

\section{References:}

Abbas, Q., Khan, A.R., Bashir, A., Alemzero, D.A., Sun, H., Iram, R., Iqbal, N., 2020a. Scaling up renewable energy in Africa: measuring wind energy through econometric approach. Environ. Sci. Pollut. Res. https://doi.org/10.1007/s11356-020-09596-1

Abbas, Q., Nurunnabi, M., Alfakhri, Y., Khan, W., Hussain, A., Iqbal, W., 2020b. The role of fixed capital formation, renewable and non-renewable energy in economic growth and carbon emission: a case study of Belt and Road Initiative project. Environ. Sci. Pollut. Res. https://doi.org/10.1007/s11356-020-10413-y

Akadiri, S. Saint, Bekun, F.V., Sarkodie, S.A., 2019. Contemporaneous interaction between energy consumption, economic growth and environmental sustainability in South Africa: What drives what? Sci. Total Environ. https://doi.org/10.1016/j.scitotenv.2019.05.421

Ali, S.A., Alharthi, M., Hussain, H.I., Rasul, F., Hanif, I., Haider, J., Ullah, S., ur Rahman, S., Abbas, Q., 2021. A clean technological innovation and eco-efficiency enhancement: A multi-index assessment of sustainable economic and environmental management. Technol. Forecast. Soc. Change. https://doi.org/10.1016/j.techfore.2021.120573

Amin, A., Liu, X.H., Abbas, Q., Hanif, I., Vo, X.V., 2021. Globalization, sustainable 
development, and variation in cost of power plant technologies: A perspective of developing economies. Environ. Sci. Pollut. Res. https://doi.org/10.1007/s11356-020-10816-X

Anser, M.K., Abbas, Q., Chaudhry, I.S., Khan, A., 2020a. Optimal oil stockpiling, peak oil, and general equilibrium: case study of South Asia (oil importers) and Middle East (oil supplier). Environ. Sci. Pollut. Res. https://doi.org/10.1007/s11356-020-08419-7

Anser, M.K., Mohsin, M., Abbas, Q., Chaudhry, I.S., 2020b. Assessing the integration of solar power projects: SWOT-based AHP-F-TOPSIS case study of Turkey. Environ. Sci. Pollut. Res. https://doi.org/10.1007/s11356-020-09092-6

Apergis, N., Payne, J.E., 2009. CO2 emissions, energy usage, and output in Central America. Energy Policy. https://doi.org/10.1016/j.enpol.2009.03.048

Belloumi, M., 2014. The relationship between trade, FDI and economic growth in Tunisia: An application of the autoregressive distributed lag model. Econ. Syst. https://doi.org/10.1016/j.ecosys.2013.09.002

Beugelsdijk, S., Smeets, R., Zwinkels, R., 2008. The impact of horizontal and vertical FDI on host's country economic growth. Int. Bus. Rev. https://doi.org/10.1016/j.ibusrev.2008.02.004

Beyzatlar, M.A., Karacal, M., Yetkiner, H., 2014. Granger-causality between transportation and GDP: A panel data approach. Transp. Res. Part A Policy Pract. https://doi.org/10.1016/j.tra.2014.03.001

Brooks, C., 2014. Introductory Econometrics for Finance, Introductory Econometrics for Finance. https://doi.org/10.1017/cbo9781139540872

Doytch, N., Uctum, M., 2011. Does the worldwide shift of FDI from manufacturing to services accelerate economic growth? A GMM estimation study. J. Int. Money Financ. https://doi.org/10.1016/j.jimonfin.2011.01.001

Gujarati, D.N., 2004. Basic Econometrics 4th Edition, Tata McGraw-Hill. https://doi.org/10.1126/science.1186874

Hanif, I., Faraz Raza, S.M., Gago-de-Santos, P., Abbas, Q., 2019. Fossil fuels, foreign direct investment, and economic growth have triggered $\mathrm{CO} 2$ emissions in emerging Asian economies: Some empirical evidence. Energy. https://doi.org/10.1016/j.energy.2019.01.011

Hazari, B.R., A-Ng, 1993. An analysis of tourists' consumption of non-traded goods and services on the welfare of the domestic consumers. Int. Rev. Econ. Financ. https://doi.org/10.1016/1059-0560(93)90030-T

Hazari, B.R., Sgro, P.M., 1995. Tourism and growth in a dynamic model of trade. J. Int. Trade Econ. Dev. https://doi.org/10.1080/09638199500000019

Herzer, D., Klasen, S., Nowak-Lehmann D., F., 2008. In search of FDI-led growth in developing countries: The way forward. Econ. Model. https://doi.org/10.1016/j.econmod.2007.11.005

Huang, Y., Raza, S.M.F., Hanif, I., Alharthi, M., Abbas, Q., Zain-ul-Abidin, S., 2020. The role of forest resources, mineral resources, and oil extraction in economic progress of developing Asian economies. Resour. Policy. https://doi.org/10.1016/j.resourpol.2020.101878

Iqbal, N., Khan, A., Gill, A.S., Abbas, Q., 2020. Nexus between sustainable entrepreneurship and environmental pollution: evidence from developing economy. Environ. Sci. Pollut. Res. https://doi.org/10.1007/s11356-020-09642-y

Iqbal, W., Fatima, A., Yumei, H., Abbas, Q., Iram, R., 2020. Oil supply risk and affecting parameters associated with oil supplementation and disruption. J. Clean. Prod. https://doi.org/10.1016/j.jclepro.2020.120187

Iram, R., Anser, M.K., Awan, R.U., Ali, A., Abbas, Q., Chaudhry, I.S., 2020. Prioritization of Renewable Solar Energy To Prevent Energy Insecurity: An Integrated Role. Singapore Econ. Rev. https://doi.org/10.1142/s021759082043002x

Li, H.A.O., Bhatti, Z., Abbas, Q., Ahmad, I., Iqbal, N., Aziz, B., 2020. MEASURING LOW CARBON ENERGY, ECONOMIC and ENVIRONMENTAL SUSTAINABILITY PERFORMANCE of BRICS. Singapore Econ. Rev. https://doi.org/10.1142/S0217590820500617 
Li, X., Liu, X., 2005. Foreign Direct Investment and economic growth: An increasingly endogenous relationship. World Dev. https://doi.org/10.1016/j.worlddev.2004.11.001

Liu, J., Abbas, Q., Alharthi, M., Mohsin, M., Rasul, F., Iqbal, N., 2021. Managerial policy and economic analysis of wind-generated renewable hydrogen for light-duty vehicles: Green solution of energy crises. Environ. Sci. Pollut. Res. https://doi.org/10.1007/s11356-02011018-1

Qayyum, M.A., Bashir, F., Maqbool, M.M., Ali, A., Bashir, S., Abbas, Q., 2019. Implications of saline water irrigation for linseed on seed germination, seedling survival and growth potential. Sarhad J. Agric. https://doi.org/10.17582/JOURNAL.SJA/2019/35.4.1289.1297

Sahban, M.A., Abbas, Q., 2018. Comparison of Conflict Management Style Between Malaysian and Thai Employees: A Case Study in Top Glove Corporation. J. Bus. Soc. Rev. Emerg. Econ. https://doi.org/10.26710/jbsee.v4i2.244

Samad, A., 2009. Does FDI Cause Economic Growth? Evidence from South-East Asia and Latin America. Utah Val. Univ.

Shen, H., Ali, S.A., Alharthi, M., Shah, A.S., Khan, A.B., Abbas, Q., Rahman, S.U., 2021. Carbon-free energy and sustainable environment: The role of human capital and technological revolutions in attaining sdgs. Sustain. https://doi.org/10.3390/su13052636

Sun, H., Khan, A.R., Bashir, A., Alemzero, D.A., Abbas, Q., Abudu, H., 2020. Energy insecurity, pollution mitigation, and renewable energy integration: prospective of wind energy in Ghana. Environ. Sci. Pollut. Res. https://doi.org/10.1007/s11356-020-09709-w

Tohidy Ardahaey, F., 2011. Economic Impacts of Tourism Industry. Int. J. Bus. Manag. https://doi.org/10.5539/ijbm.v6n8p206

World Travel \& Tourism Council, 2018. Travel \& Tourism Economic Impact 2018 World, Travel and Tourism Impact 2018. https://doi.org/10.1093/elt/ccr029

Xia, Z., Abbas, Q., Mohsin, M., Song, G., 2020. Trilemma among energy, economic and environmental efficiency: Can dilemma of EEE address simultaneously in era of COP 21? J. Environ. Manage. https://doi.org/10.1016/j.jenvman.2020.111322

Yang, Z., Abbas, Q., Hanif, I., Alharthi, M., Taghizadeh-Hesary, F., Aziz, B., Mohsin, M., 2021. Short- and long-run influence of energy utilization and economic growth on carbon discharge in emerging SREB economies. Renew. Energy. https://doi.org/10.1016/j.renene.2020.10.141 